ppi $201502 Z U 4645$

Esta publicación científica en formato digital es continuidad de la revista impresa ISSN-Versión Impresa 0798-1406 / ISSN-Versión on line 2542-3185Depósito legal pp $197402 Z$ U34
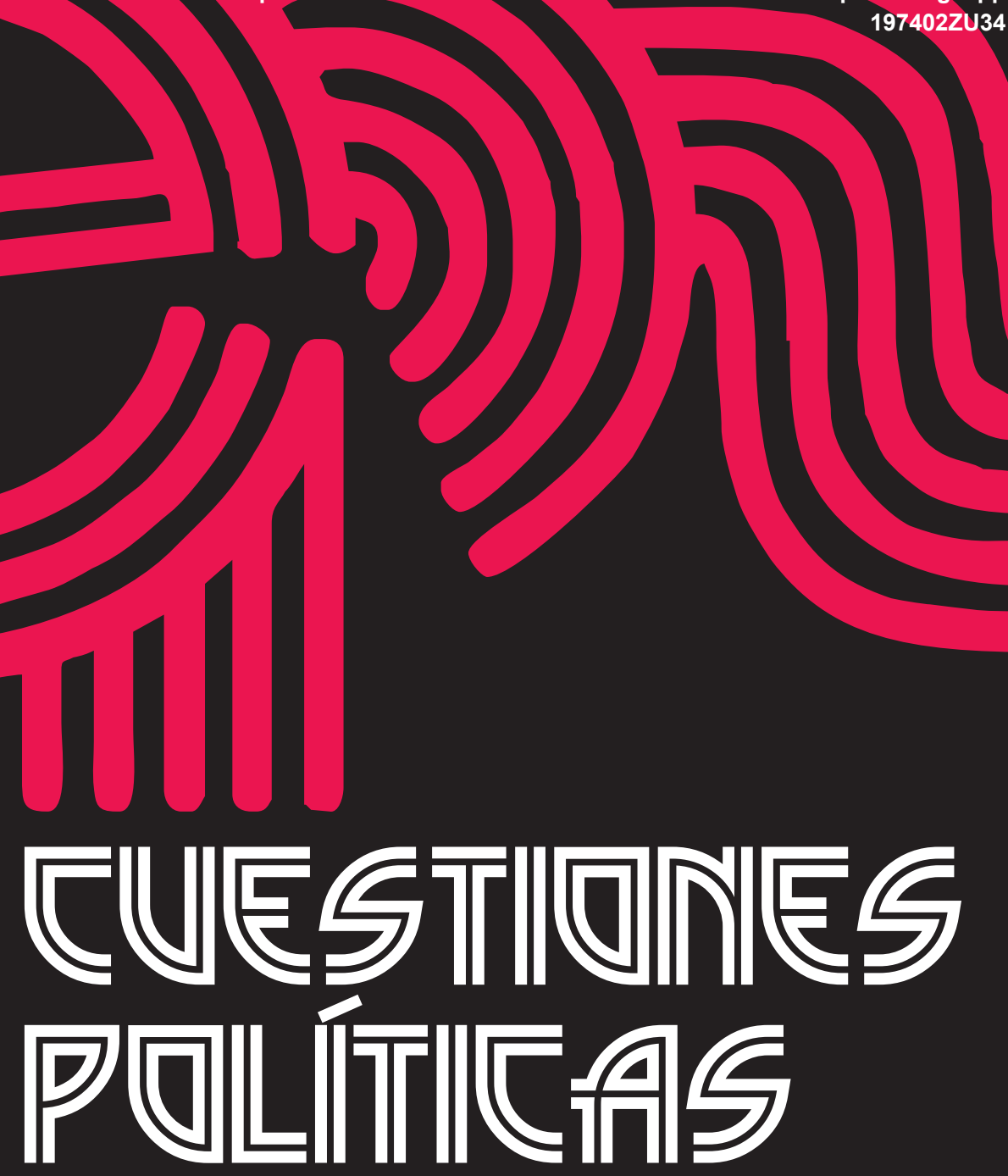

Instituto de Estudios Políticos y Derecho Público "Dr. Humberto J. La Roche" de la Facultad de Ciencias Jurídicas y Políticas de la Universidad del Zulia Maracaibo, Venezuela
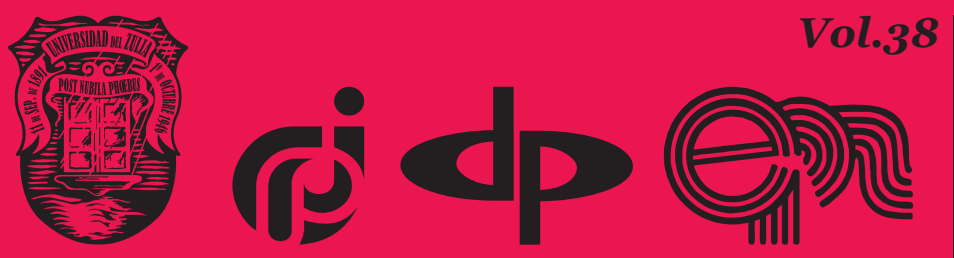

$N^{\circ}$ Especial 2da Parte 2020 


\title{
Security in Rights as a Variety of National Security
}

\author{
DOI: https://doi.org/10.46398/cuestpol.382e.04
}

\author{
Guzel Anvarovna Valeeva* \\ Dmitry Anatolyevich Lipinsky ** \\ Valerii Gennadievich Golubcov ***
}

\begin{abstract}
Study purpose is to determine the signs of legal security on the basis of existing scientific views and current legislation, excluding its overly broad understanding, leading to the fact that any legal requirement is included in the content of national security. Methodology: the basis is the dialectical method of cognition of the facts of social reality, on which the formal legal and comparative legal approaches are largely based. The methods of analysis and synthesis, abstraction, deduction and induction have found their application both individually and as part of other methods. Main content. We analyzed the features of legal security: normative; legal system stability; focus on eliminating legal threats and others, as well as criticized the widespread understanding of legal security as a form of national security. Conclusions. It is proved that it is necessary to distinguish between such phenomena as legal security and legal security as a form of national security, while the latter is part of legal security. In general, the entire block of legal security is not included in the content of
\end{abstract} national security.

Keywords: national security; security rights; legal security; signs of legal security; security strategy.

\footnotetext{
* Kazan Federal University,Candidate of History, Law Faculty of Kazan Federal University. ORCID ID: https://orcid.org/oooo-0oo2-7895-8134. Email: valeeva@icloud.com

** Togliatti State University,Doctor of Law. ORCID ID: https://orcid.org/oooo-0003-1870-069X. Email: Dmitri8@yandex.ru

*** Perm State University, Professor, head of the Department of business law, civil and arbitration procedure of the Perm state national research University. ORCID ID: https://orcid.org/oooo-00033505-2348. Email:vg2009@yandex.ru
} 


\section{La seguridad de los derechos como una variedad de seguridad nacional}

\section{Resumen}

El propósito del estudio es determinar los signos de seguridad jurídica sobre la base de los puntos de vista científicos existentes y la legislación vigente, excluyendo su comprensión excesivamente amplia, lo que lleva a que cualquier requisito legal esté incluido en el contenido de la seguridad nacional. Metodología: la base es el método dialéctico de conocimiento de los hechos de la realidad social, en el que se basan en gran medida los enfoques jurídicos formales y jurídicos comparados. Los métodos de análisis y síntesis, abstracción, deducción e inducción han encontrado su aplicación tanto individualmente como como parte de otros métodos. Contenido principal. Analizamos las características de la seguridad jurídica: normativa; estabilidad del sistema legal; se centran en eliminar las amenazas legales y otras, así como critican la comprensión generalizada de la seguridad jurídica como una forma de seguridad nacional. Conclusiones. Está comprobado que es necesario distinguir entre fenómenos como la seguridad jurídica y la seguridad jurídica como forma de seguridad nacional, mientras que esta última forma parte de la seguridad jurídica. En general, todo el bloque de seguridad jurídica no está incluido en el contenido de seguridad nacional.

Palabras clave: seguridad nacional; derechos de seguridad; seguridad jurídica; signos de seguridad jurídica; estrategia de seguridad.

\section{Introduction}

First of all, it is necessary to note the features of the study object and pay attention to the article title. Thus, two relatively new scientific areas have been actively developing in science in recent years. Firstly, they include a study of national security, within the framework of which the efforts of specialists in various fields of scientific knowledge (lawyers, economists, political scientists, philosophers, sociologists, managers, representatives of technical sciences, etc.) are integrated. At the same time, national security is examined from its own point of view, taking into account the specific features of the subject and method of a particular science, but, at the same time, the achievements of the closest branches of scientific knowledge are actively used, since national security is a complex problem. Secondly, they include the study of legal security or compliance, as an integral part (variety) of national security. Scientific research takes place both from the 
general to the particular, and from the particular to the general Thus, there are works devoted not only to the general theoretical problems of legal security, but also studies taking into account its division, both on the basis of the branches of law and the branches of legislation.

\section{Methods}

We used such general scientific methods of cognition as: analysis method, system research method; private scientific methods: method of comparative law, formal-legal method, intersectoral method of legal research.

\section{Results and discussion}

It is necessary to identify common signs of legal security and give its concept. Thus, according to I.S. Lapaev, compliance is:

A state of security (protection, assurance) and streamlining of the vital interests of legal entities associated with their entry into the field of legal relations, due to effective lawmaking, uniform enforcement, stability and legal certainty of legal relations, high legal awareness (Lapaev, 2013: 29).

Khokhloev I.A. believes that:

Compliance in the conditions of prevention and liquidation of emergencies is a state of protection of the vital interests of public relations subjects in the field of prevention and liquidation of emergencies, where these entities can fully exercise their rights in accordance with applicable regulatory legal acts, demand from other entities the right to perform duties without fear of harm to life, health or property, as well as the state in which, regardless of adverse circumstances, the law implementation mechanism and the protection mechanism for the fundamental rights and freedoms of human and society are operated (Khokhloev, 2008: 52).

According to T.B. Tyurina, "legal security of an individual is one of the types of personal security and is defined as the state of protection of his/ her vital interests from the external and internal threats in the field of legal relations" (Tyurina, 2005: 58). The author proceeds from the need to determine legal security in two interrelated aspects. Firstly, legal security as a condition, and secondly, as a process of ensuring. Legal security in the form of a state is characterized by the absence of various threats, as well as the presence of legal that can level such threats. The process of legal 
security itself already appears in the form of actions (dynamics) of various legal means used by the subject to eliminate the threat (Tyurina, 2005).

G.G. Gorshenkov defines legal security from the position of "the state of legal protection of an object in the presence of its necessary legal guarantees and legal support of normal life" (Gorshenkov, 2009: 44). V.A. Osipov proposes to consider legal security from a wide and narrow perspective. In his opinion, "legal security in the broad sense characterizes the protection of various spheres of life (state, political, economic, spiritualmoral, information, environmental, social, etc.) by legal means, because it is impossible to ensure national security without legal mediation in modern conditions" (Osipov, 2009: 22). In the narrow sense, it (legal security) is determined through the category of security of the legal system of society with the help of legal means, based on legal regulation (Osipov, 2009).

V.A. Osipov is not the first researcher who proposes to consider legal security in a narrow and a broad sense. Thus, according to A.F. Galuzin:

In the broad sense, it represents the security of legal system, and within the framework of law, legislation and other elements, its protection from dangers and threats of a legal nature, legal means to ensure all types of security (economic, political, natural and technological, etc.), in the narrow sense - this is an activity to prevent and minimize legal dangers and threats both in the law-making and law enforcement process (Galuzin, 2008: 41).

The author, developing his concept, notes in another work that: "Legal security as an independent type of security is the protection of regulatory legal acts and enforcement from "legal" dangers, which determines the legal quality of security and secured types of social security through legislation and enforcement without risks" (Galuzin and Romashov, 2012: 42). The feature of A.F. Galuzina's position is the definition of legal security from the opposite, and most likely paired category - legal danger.

Other researchers provide concise definitions of legal security. For example, according to A.A. Ter-Akopova, it represents "a state of legal protection of the vital interests of the individual (society and state) from the external and internal threats" (Ter-Akopov, 2001: 11). B.V. Dreyshev also states his position very briefly. Thus, he indicates that: "Legal security should be understood as the state of security of the legal system" (Dreyshev, 1998: 18). A.S. Shaburov considers the legal security in a similar way. He writes that "legal security is the security of the law itself. This is the security of the legal system" (Shaburov, 2015).

Thus, despite the presence of a variety of concepts and approaches to legal security, the authors, revealing its features, use such concepts as: "state of security"; "threat"; "legal means", "interests", which brings them 
together in many ways. Legal security is considered both in a static and in a dynamic state. The legal security objects are the legal system as a whole, as well as its elements such as the legal system and the legislation system.

At the same time, there was a tendency to distinguish two areas in understanding legal security. Firstly, it is considered as a state of guaranteeing the rights and legitimate interests of participants in legal relations created by legal methods, as a result of which the security of legal entities is ensured in various fields (environmental, financial, military, etc.). Secondly, it is understood as a special state of security of the legal system of society through law, law-making and law enforcement, that is, exclusively by legal means against legal threats.

It seems that both approaches are not mutually exclusive, but the first gravitates most to the concept of "legal regulation of national security". It seems that it is necessary to highlight the optimal "middle ground" between two approaches, which would not allow the phenomenon of legal security to turn into an infinitely broad concept. In view of the global regulation of public relations, penetration of law into an increasing number of the life fields of a state-organized society, the legal institutionalization of security, as such, and national, in particular, within which there is a special block of legal security, is ongoing.

Based on the foregoing, we can distinguish the most common signs of legal security, namely: formalization in legal norms of a different level of basic values of national security and threats; streamlining the interaction of social actors with the help of the power regulator - the law through which models of such interaction are created (institutionalized); direct or indirect participation in legal security relations of the state; high level of development of legal relations in society.

Based on the general signs of legal security, it is possible to determine its particular features, which more relate to legal security as an object of law enforcement activity, sincelegal security is not only a static phenomenon, but a process in which the threats are eliminated. Despite the very importance of the institutional aspect of legal security, the adoption of another law or by-law does not solve anything in itself, since its implementation and adjustment mechanisms are necessary, if there are various kinds of legal defects in it. The main drawback of all regulatory enactments regulating this area is the lack of systematic nature. Thus, ensuring legal security takes shape in two main areas: law-making and law enforcement, which means that it can be argued that there are two of its components in legal security. Firstly, it is a law-making component, the result of which is a high-quality regulatory legal act institutionalizing national security. Secondly, it is law enforcement, where extrapolation and implementation into reality of the result achieved within the framework of the law-making process takes place. 
When the specific features of legal security are defined, it is also necessary to indicate a number of its other features. Thus, it appears in the form of a special property of the legal system, the state of individual, society and state. Then, "legal security from a functional point of view is also a certain activity, a form of purposeful activity of some entities related to law and legal sphere" (Fomin, 2007: 466). Another feature of legal security is its extension to both the protection objects and the sources of dangers in a particular sphere. It should be particularly emphasized the extension of security not to all interests, but only to the most vital ones. Another legal security features is its quantitative and qualitative indicators related to the legal field, living space (which is protected), where the interests of the law subjects are implemented.

The following feature of legal security is associated with the stability of the legal system (Burke-White, 2004), especially such elements as the legal system and the legislation system. The endless amendments to regulatory legal acts that are not caused by objective processes in public relations negatively affect legal security. The legal system cannot be stable without a uniform law enforcement process.

Earlier, we, like other researchers (Itzhak, 2016), pointed out that an important feature of legal security is the protection of precisely the basic vital interests of the society's and state's individual. In this context, it is necessary to turn to our assumption made at the very beginning of this article that legal security is only a part of the national security. This issue formulation is due to the fact that the law mediates most areas of society and various types of security. The "National Security Strategy", approved by the Decree of the President of the Russian Federation No. 683 dated 31.12.2015, states that "national security includes the country's defense and all types of security stipulated by the Constitution of the Russian Federation and the legislation of the Russian Federation, primarily state, public, informational, environmental, economic, transport, energy, as well as personal security". Thus, the strategy actually makes the list of types of national security open, creating legal uncertainty. In this regard, they began to write about food, educational, religious, cultural security as types of national security in legal science.

Based on this thesis, we can inevitably conclude that legal security in all these areas is a form of national security. Researchers (Donohue, 2011; Gordon, 2014; Williams, 2008) come to this conclusion as a result of an analysis of both the "National Security Strategy of the Russian Federation" and other regulatory legal acts in which various types of security are classified as national, for example, the Decree of the President of the Russian Federation No. 120 dated 30.01.2010 "On Approval of the Doctrine of Food Security of the Russian Federation"; the Resolution of the Government of the Russian Federation No. 1734 dated 22.11.2008 "Transport Strategy of the Russian Federation Until 2030" and others. 
The economy and economic growth in the National Security Strategy are called national priorities and interests, and an unfavorable trend in the economy development, a lag in technological progress - the threats to life quality. The threats to economic growth include various types of economic offenses in a generalized form. If we turn to the level of a single, for example, particular infringement on the property of a citizen or a legal entity, and taking into account that the regulatory definition of national security contains the wording "the security state of an individual, society and state from the internal and external threats...", we can conclude that such an infringement is an offense against national security.

\section{Conclusions}

1. When determining the criteria whereon a particular block (part) of legal security will be included in the national security structure, it is necessary to proceed from a number of factors that should be identified, including using methods of other sciences (which are not legal). Firstly, they should be based on various kinds of statistical data, as well as expert assessments of latent offenses. On their basis, it is shown how certain processes are global and threaten a certain type of national security. Secondly, it should be borne in mind that certain legal threats (sometimes even single ones) in the regulation of critical infrastructures of potentially dangerous activities can lead to disastrous consequences for the entire cities, regions, affect the security of a significant number of citizens. Thirdly, it is necessary to take into account the fundamental international regulatory legal acts that counteract such negative phenomena as terrorism, extremism, slave trade, money laundering, etc.

2. 2. The concepts of "legal security" and "legal security as a form of national security" are not identical. Legal security as a form of national security is part of general legal security. Moreover, we can call it the backbone of all legal security. This phenomenon is not static, but dynamic, which is constantly transforming due to the emergence of new types of threats and changes in the existing ones.

By last, the legal security direction definitely refers to the new and rapidly developing. There are several approaches to determining legal security. The complexity of this category lies in the lack of a clear scientific definition and such basic components as principles, goals, functions and support means. 


\section{Acknowledgements}

The work is performed according to the Russian Government Program of Competitive Growth of Kazan Federal University.

\section{Bibliographic References}

BURKE-WHITE, William. 2004. "Human rights and national security: the strategic correlation" In: Harv. Hum. Rts. J. Vol. 17, p. 249.

DREYSHEV, Billy. 1998. "Legal Security and the Problem of its Provision" In: University News. Jurisprudence. Vol. 2, pp. 11-19.

FOMIN, Aleksandr Aleksandrovich. 2007. Legal Security of the Russian Law Subjects (Issues of Theory and Practice): Thesis for the Doctor of Law. Penza, Russia.

GALUZIN, Andre. 2008. Legal Security and its Principles. Publishing House of R. Aslanov "Legal Center Press". St. Petersburg, Russia.

GALUZIN, Andre; ROMASHOV, Roman Anatolyevich. 2012. Legal and Penitentiary Security: Correlation of Concepts In: Materials of the International Scientific-Practical Conference. Samara FSIN, Russia.

GORDON, Neve. 2014. "Human Rights as a Security Threat: Lawfare and the Campaign against Human Rights NGOs” In: Law \& Society Review. Vol. 42. No. 2.

GORSHENKOV, Gealinda. 2009. Anti-Criminal Security of an Individual: Abstract of a Thesis for the Doctor of Law. Stavropol, Russia.

ITZHAK, Zeev. 2016. Human Rights and National Security. Cambridge University Press. Cambridge, UK.

KHOKHLOEV, Iuies. 2008. Legal Security Provision Mechanism for the Prevention and Liquidation of Emergency Situations: Abstract of a Thesis for the Candidate of Law. St. Petersburg, Russia.

LAPAEV, Ieonard. 2013. Legal Security Provision Mechanism in the Russian Federation (Ttheory and Practice): Thesis for the Candidate of Law. Penza, Russia. 
DONOHUE, Laura Kate. 2011. The Limits of National Security Symposium: Moving Targets: Issues at the Intersection of National Security \& American Criminal Law Donohue. Georgetown University Law Center. USA.

OSIPOV, Vladimir. 2009. Legal Security Mechanism in Modern Society: Abstract of a Thesis for the Candidate of Law. Penza, Russia.

SHABUROV, Alexander. 2015. "Legal Security in the National Security System" In: Bulletin of the SUSU. "Pravo" Series. Vol. 3, pp. 24-30.

TER-AKOPOV, Aleksandr. 2001. "Legal Security of a Person in the Russian Federation (concept basis) " In: State and Law. Vol. 9, pp. 11-13

TYURINA, Teodor. 2005. Legal Security of an Individual in a Modern Russian State: Abstract of a Thesis for the Candidate of Law. Saratov, Russia.

WILLIAMS, Paul. 2008. Security Studies: An Introduction. Routledge, UK. 
Vol.38 NEspecial

Esta revista fue editada en formato digital y publicada en diciembre de 2020, por el Fondo Editorial Serbiluz, Universidad del Zulia. Maracaibo-Venezuela 